Vol. 8, No. 1, 2020, pp. 23-31

DOI: https://doi.org/10.29210/139900

Contents lists available at Jurnal IICET

Jurnal Konseling dan Pendidikan

ISSN: 2337-6740 (Print) ISSN: 2337-6880 (Electronic)

Journal homepage: http://jurnal.konselingindonesia.com

\title{
Organizational behavior management through group counseling discussions as a radicalism preventive effort
}

\author{
Dina Hajja Ristianti ${ }^{1}$, Guntur Putra Jaya ${ }^{2}$, Irwan Fathurrochman ${ }^{3}$ \\ ${ }^{123}$ Institut Agama Islam Negeri (IAIN) Curup, Indonesia
}

\author{
Article Info \\ Article history: \\ Received Des 23rd, 2019 \\ Revised Jan 27th, 2020 \\ Accepted Feb 13th, 2020
}

\section{Keyword:}

Group Counseling

Organizational Management

Radicalism

\begin{abstract}
Lembaga dakwah kampus (LDK) or Da'wah organization in campus as a student organization that concentrates on the Islamic teaching. This research uses a descriptive approach. In general, this study describes the behavior of radicalism and organizational behavior management among students of LDK members in IAIN Curup and the effect of group counseling activities on radicalism and organizational behavior management. To measure radicalism in this study is to use a closed questionnaire, the questionnaire was arranged based on the lattice that has been made based on theory by determining variables, sub variables and indicators of research. The researcher wanted to see the management of organizational behavior through the Group Counseling Disscussions as a radicalism preventive effort at Da'wah organization in IAIN Curup. Moreover, the findings show that, among the Da'wah organization's members, radicalism it indicates that the behavior of radicalism in the category is quite radical. Group dynamics that occur in group counseling discussions are also good as seen from the enthusiasm and cohesiveness of students in discussions. The radicalism behavior and organizational behavior management before being given group counseling discussion activities are not the same as radicalism behavior and organizational behavior management after group counseling discussions.
\end{abstract}

\section{Corresponding Author:}

Dina Hajja Ristianti,

Institut Agama Islam Negeri (IAIN) Curup

Email: dinahajja@iaincurup.ac.id

\section{Introduction}

Radicalism is considered a common symptom that occurs in a society who want changes. Syafii Maarif explained that radicalism is more related to the model of attitudes and ways of expressing one's religion which is motivated by social, political, cultural and religious conditions (Fanani, 2013). Radicalism can turn into terrorism. Various events and research among students have proven. One of the is the incident in 2018, the Special Detachment Team 88 succeeded in securing 3 suspected terrorists with a number of items of evidence, including 4 bombs ready to explode at the University of Riau. This incident proves that all kinds of methods carried out by the campus, such as monitoring, controlling and giving direction so as not to be exposed to radicalism, the students are still involved in acts of radicalism (Novitra, 2018).

Why students exposed to radicalism? (Jones et al., 2015) explains that there are two sides, the psychological side and the sociological side. Psychologically, it is caused by the transition phase in the age growth experienced by young people, making them more vulnerable to experiencing or common known as 'identity crisis' (Erikson, 2018). What happens in the 'identity crisis' makes it possible for young people to experience what Quintan W calls cognitive opening, a micro-sociological process that draws them closer to accepting more radical ideas. After this identity crisis and finding new understandings that are more acceptable, young people will carry out identity actions with the slogan 'I am radical, that makes me exist and meaningful. Meanwhile, in terms of sociology, why young people are involved in radicalism, this is 
because young people are considered as agents of change. As an agent of change, young people occupy crucial positions as mediators in societal reproduction and social transformation (Harrington \& Manji, 2017). Coupled with the existence of injustice both socially and politically so that it creates moral sock where an unexpected event or information causes feelings of anger or anger that ultimately makes young people involved in political action whether it is known or not (Auwärter, 2014).

Ahmad Fuad Fanani explains that there are two indicators of a radicalism, that's are radical thinking and radical attitude (Fanani, 2013). Radical thinking is the desire of someone to replace the 1945 Constitution with the Quran and the Hadith as the basis of the Indonesian state and the desire to implement Islamic sharia which ultimately makes a person have a radical understanding in which a person is exclusivist who only associates with people on only the environment and do not want to interact with people who come from outside the environment (Fadli et al., 2019).

While radical is related to violent behavior in the name of jihad (Davids, 2017). This violent behavior is carried out because it opposes disobedience, opposes heresy, opposes the establishment of churches without permission and opposes Israel in Palestinian attacks, raids (sweeping) to places that are contrary to religion (Khozin, 2013). Whereas supposed to be a student is not a radical action that is shown because students are people who are wise, knowledgeable and tolerant (Qodir, 2014).

A good organization needs good management of organizational behavior (Supriadi et al., 2019). Organizational behavior is the study of factors that influence individuals and groups in responding and acting towards organizations and responding to how organizations manage their environment (Acadia, 2019; Van Der Pas \& Walczuch, 2019). The study of organizational behavior provides guidance to understand and appreciate the many individual forces that influence behavior in organizations, and to improve decisions on how to motivate and coordinate human and other resources in achieving organizational goals (Moagi et al., 2020; Van Der Pas \& Walczuch, 2019). The elements of organizational behavior are: (1) individual differences both in terms of personality and abilities, (2) work experience both in terms of values, attitudes, and the atmosphere (modes), (3) perception (perception) and attribution (attribution), and (4) commitment, motivation, endurance / stress, and performance (performance).

In behavioral management, one of the important things here is leadership style (Erlygina \& Abramova, 2019). Quoted from Badu, Syamsu Q and Djafri, (Novianty, 2019) that the style of leader who gives authority is a style of democratic or participatory leadership. This style leads the leader to involve members as a whole team in resolving the case at hand (Susilawati et al., 2020). The leader provides all the information related to the duties, jobs and responsibilities of its members (Trijayanti et al., 2019). Subordinates play a major role in a democratic leadership style where a superior only tells the target to be achieved and how to achieve it, and the members determine (Cornish et al., 2012a, 2012b).

Furthermore, members are given flexibility in following up on problems that occur (Tajri \& Chandra, 2018). Democratic leadership is very compatible with members who are highly competent and have a variety of commitments, and is characterized by a structure created based on a joint decision making approach (Fathurrochman, 2017).

Mary Bland states that Group Counseling Discussions or often called Group Counseling is a process between individuals containing therapeutic characteristics created such as the free expression of thoughts and feelings, orientation to reality, opening up about deep feelings experienced, mutual trust, mutual concern, mutual understanding and mutual support (Bland et al., 1986). Meanwhile Mei-whei Chen and Christopher Rybak states that Group Counseling Discussion is an activity in Guidance and Counseling that utilizes group dynamics to discuss and understand group members' problems and help solve these problems together led by a group leader (Chen \& Rybak, 2020).

Therapeutic characteristics are created and fostered in a small group by expressing personal difficulties and concerns to fellow group members and counselors (Diab et al., 2020). Group members are people who face various problems that do not require changes in personality structure (Cornish et al., 2012b). (Sepehrian Azar \& Saadatmand, 2015) sates that Group members can utilize the interpersonal atmosphere within the group to increase understanding and acceptance of life values and life goals, as well as to learn or eliminate certain attitudes and behaviors as mentioned by (Prayitno \& Amti, 1999; Ristianti et al., 2019; Winkel, W. S., \& Hastuti, 2005).

Group counseling services are guidance and counseling services that allow clients to get the opportunity to discuss and alleviate the problems they experience through group dynamics, the problems discussed are personal problems experienced by each group member (Wibowo, 2005; Winkel, W. S., \& Hastuti, 2005). 
Group counseling is basically individual counseling services carried out in a group setting. There are counselors (of which there may be more than one) and there are clients, namely group members (with at least two people) (Thapa et al., 2020). There occurs counseling relationships in an atmosphere that is attempted the same as in individual counseling, which is warm, open, permissive, and full of intimacy (Moagi et al., 2020). At that time there is also the disclosure and understanding of client problems, delineation of causes of problems, problem solving efforts (if necessary apply specific methods), evaluation of activities and follow-up (Berg, R. C., Landreth, G. L., \& Fall, 2013; Winkel, W. S., \& Hastuti, 2005). From this it can be understood that group counseling discussion is appropriate to be used to manage organizational behavior in order to avoid the behaviors of radicalism (Muazza et al., 2018; Walton, 2020).

\section{Method}

This research uses a descriptive approach (Ristianti, 2017). In general, this study describes the behavior of radicalism and organizational behavior management among students of LDK members in IAIN Curup and the effect of group counseling activities on radicalism and organizational behavior management. To measure radicalism in this study is to use a closed questionnaire, the questionnaire was arranged based on the lattice that has been made based on theory by determining variables, sub variables and indicators of research. Lehmann explained that descriptive research is one type of research that aims to describe systematically, factually and accurately about the facts and nature of certain populations, or try to describe phenomena in detail (Yusuf, 2016).

The characteristics of descriptive research according to (Ifdil et al., 2019; Taufik et al., 2019) is to focus on solving existing problems or problems / events that are current and meaningful and this research is intended to give/host regarding situations or events precisely and accurately (Ristianti et al., 2019).

The population in this study is Da'wah organization at IAIN Curup, amounting to 50 people. The sampling technique in this study was purposive sampling which is the technique of determining the sample with certain considerations which only examined from the core administrators of Da'wah organization at IAIN Curup. The variables, sub variables and indicators can be seen at this figure.

Table 1. Questionnaire Grilles in the research of Organizational behavior management through group counseling discussions as a radicalism preventive effort

\begin{tabular}{|c|c|c|c|}
\hline No. & Variables & Sub Variables & Indicators \\
\hline \multirow[t]{2}{*}{1.} & $\begin{array}{l}\text { Radicalism } \\
\text { Behavior }\end{array}$ & Radical Thought & $\begin{array}{l}\text { 1. Someone's desire that Indonesia become an } \\
\text { Islamic State, } \\
\text { 2. And the next indicators. }\end{array}$ \\
\hline & & Radical attitude & $\begin{array}{l}\text { 1. Violent behaviour against immorality, } \\
\text { 2. And the next indicators. }\end{array}$ \\
\hline 2. & $\begin{array}{l}\text { Organizational } \\
\text { Behavior } \\
\text { Management }\end{array}$ & $\begin{array}{l}\text { Democratic leadership } \\
\text { style }\end{array}$ & $\begin{array}{l}\text { 1. Invite to solve problems together, } \\
\text { 2. And the next indicators. }\end{array}$ \\
\hline
\end{tabular}

\section{Results and Discussion \\ Overview of radicalism behavior}

The instruments processed were 10 copies. For the questionnaire of radicalism behavior among students in LDK Cahaya Islamic IAIN Curup consisted of 18 items of statement items with a range of scores 1-5. For these 18 items, an ideal score of 90 and a minimum score of 18. The results of the calculation of data on the behavior of radicalism among students obtained a description of the behavior of radicalism among administrators of LDK Cahaya Islami IAIN Curup, with an average score of 57.9 indicating that the behavior radicalism in the quite radical category.

\section{Overview of organizational behavior management}

The instruments processed were 10 copies. For the organizational behavior management questionnaire among the administrators of LDK Cahaya Islami IAIN Curup consisted of 10 items of statement items with 
a range of scores 1-5. For these 10 items, the ideal score is 50 and the minimum score is 10 . The results of the calculation of the data on the organizational behavior management among students obtained an overview of the management of organizational behavior among the administrators of LDK Cahaya Islami IAIN Curup is 38.8 .

\section{Group counseling discussion as an organizational behavior management effort in preventing radicalism among students members of LDK Cahaya Islam IAIN Curup.}

Group counseling discuss is carried out at the IAIN Curup campus to the organizers of the IAIN Curup Campus Islamic Propagation Institute (LDK). The implementation of group counseling discuss can be carried out in two meeting sessions that have been agreed between the counselor as a researcher and student as the object of research.

The first stage in group counseling discuss activity is the introduction phase, the involvement phase or the stage of entering oneself into the life of the group. In this formation the group leader explains the goals to be achieved through group activities and explains the ways that should be traversed in achieving the goals. Furthermore, the leader states explaining his role as a group leader with and communication that contains elements of respect for group members, sincerity, warmth and empathy. This was revealed by several group members that "In this group counseling activity we get an explanation of the purpose of group counseling and we feel that mothers care about us as the organizers of the organization".

In this initial stage, the group leader fosters group attitudes and group feelings. This togetherness starts with playing a "series of hobbies" to all group members. From this activity, students revealed that "we feel excited about the series of hobby games, because we know the hobbies of our friends. We feel happy because we are getting closer to friends and feel there is togetherness in this group ". With a sense of joy and togetherness, the group leader invites group members to start the activity. The group leader described the rampant radicalism behavior among students and the most highlighted were students who were active in the campus missionary institution. The group leader invites all group members to think about why this could happen, what are the underlying factors, what are the consequences if students commit radicalism and how to prevent students from being contaminated by radicalism viruses.

The group counseling discuss activity in the second session was conducted for the same LDK students/administrators as the previous group. The initial activity in the second session was not during the process of the initial activity of the previous session because there was still friendship and volunteerism among each member, this can be seen from their presence with the same number and people. From that, the group leader only gave a small game that is "five dot" just to give freshness and enthusiasm to the group members in carrying out group counseling discuss activities. The next activity is a group leader inviting members to think about the process of behavior management in the organization. Starting from fostering intimacy with all members of the organization, uniting organizational goals to invite all members of the organization to be able to work together to realize the organization's vision and mission.

From the implementation of the group counseling discussion activities, it can be concluded that the material which is the topic of discussion in the group is about radicalism and organizational behavior management (Yanto \& Fathurrochman, 2019). This group counseling discussion activity discusses issues of radicalism and organizational management issues, discusses the factors that cause problems and efforts that can be made so that an organization can be avoided and far from the acts of radicalism. Group dynamics that occur in group counseling discussions are also good as seen from the enthusiasm and cohesiveness of students in discussions. A description of the differences between radicalism behavior and organizational behavior management before and after group counseling is given. To get an idea of the differences between radical behavior and organizational behavior management before and after group counseling discussions, a ttest formula was performed. Based on the data obtained about the behavior of radicalism and organizational behavior management, it can be seen the difference in scores in the following table. 
Table 2. Differences in Radical Behavior and Organizational Behavior Management Before and After Group Counseling Discussions

\begin{tabular}{cccccc}
\hline \multirow{2}{*}{ No } & \multirow{2}{*}{ Students } & \multicolumn{2}{c}{ Radical behavior } & \multicolumn{2}{c}{ Organization behavior management } \\
\cline { 3 - 6 } & & Before & After & Before & After \\
\hline 1 & student-1 & 59 & 42 & 42 & 24 \\
\hline 2 & student -2 & 62 & 50 & 33 & 20 \\
\hline 3 & student -3 & 58 & 41 & 39 & 25 \\
\hline 4 & student -4 & 62 & 43 & 38 & 25 \\
\hline 5 & student -5 & 60 & 47 & 41 & 26 \\
\hline 6 & student -6 & 58 & 45 & 41 & 21 \\
\hline 7 & student -7 & 50 & 33 & 34 & 22 \\
\hline 8 & student - & 45 & 30 & 41 & 25 \\
\hline 9 & student -9 & 61 & 42 & 40 & 18 \\
\hline 10 & student -10 & 64 & 42 & 39 & 23,1 \\
\hline & Average score & 57,9 & 41,5 & 38,8 & \\
\hline
\end{tabular}

Based on the table above, it can be seen that there is an average difference between the scores of radicalism behaviors and the management of organizational behavior before and after the management of the organization participates in group counseling discussions. If guided by the class of radicalism behavior interval evaluation, the average score of radicalism behavior after attending group counseling discussions an average score of 41.5 is in the category: not radical. While organizational behavior management, after getting group counseling discussions, the average score obtained was 23.1 with the category of good organizational behavior management. To see the difference between the scores of radicalism behavior and the management of organizational behavior before and after the organization's management participates in group counseling discussions, a two-sample t-test is calculated. Based on the results of statistical analysis using SPSS type. 21 results are obtained :

\section{Radicalism behavior}

To see if there are differences in the behavior of radicalism before and after group counseling discussions through the T-Test Two Sample formula, a normality test is performed. Based on the normality test the significance value in the Shapiro-Wilk column shows that the value of radicalism behavior before and after the activities of group counseling discussions are normally distributed because the sig $>0.005$. After the normality test, a two sample $\mathrm{T}$ test is performed. Based on the SPSS statistical test results version. 21, the results obtained can be seen in the following table.

Table 3. T Test Of Radical Behavior Before And After Group Counseling Discussions

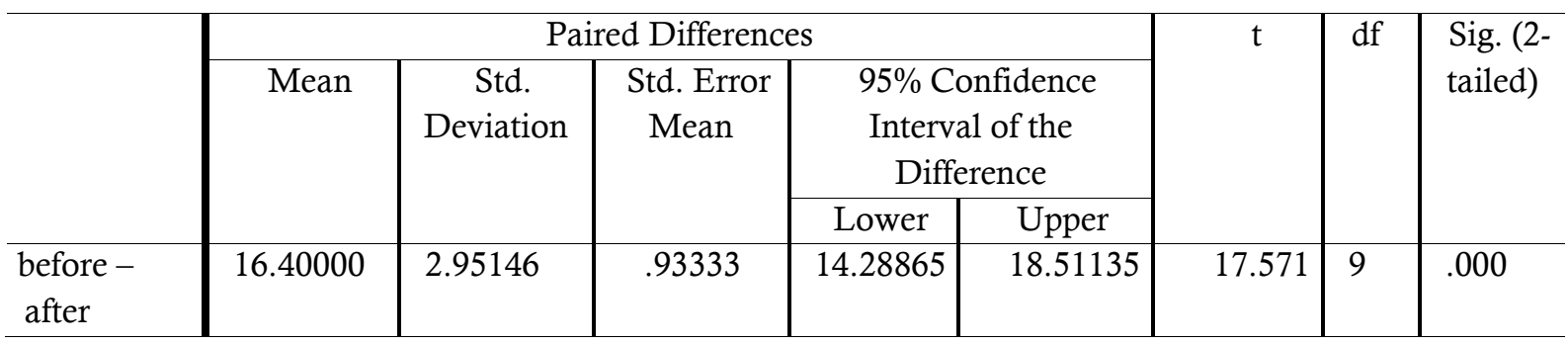

From the table above, it can be seen that the significance value indicates 0,000 where the value of sig. $<0.005$ this indicates that $\mathrm{H} 0$ was rejected and $\mathrm{Ha}$ was accepted. That means that the behavior of radicalism before is not the same as after group counseling discussions.

\section{Organizational behavior management}

To see if there are differences in the management of organizational behavior before and after group counseling discussions through the Two Sample T-Test formula, a normality test is performed. Based on the radicalism behavior normality test, the significance value in the Shapiro-Wilk column shows that the value of the management of organizational behavior before and after the activities of group counseling discussions are 
normally distributed because the sig $>0.005$. After the normality test, a two sample $\mathrm{T}$ test is performed. Based on the SPSS statistical test results. 21, the results obtained can be seen in the following table.

Table 4. T Test Results of Organizational Behavior Management Before and After Group Counseling Discussions

\begin{tabular}{|c|c|c|c|c|c|c|c|c|}
\hline & \multicolumn{5}{|c|}{ Paired Differences } & \multirow[t]{3}{*}{$\mathrm{t}$} & \multirow[t]{3}{*}{$\mathrm{df}$} & \multirow{3}{*}{$\begin{array}{l}\text { Sig. (2- } \\
\text { tailed) }\end{array}$} \\
\hline & \multirow[t]{2}{*}{ Mean } & \multirow[t]{2}{*}{$\begin{array}{c}\text { Std. } \\
\text { Deviation }\end{array}$} & \multirow[t]{2}{*}{$\begin{array}{l}\text { Std. Error } \\
\text { Mean }\end{array}$} & \multicolumn{2}{|c|}{$\begin{array}{c}95 \% \text { Confidence Interval } \\
\text { of the Difference }\end{array}$} & & & \\
\hline & & & & Lower & Upper & & & \\
\hline $\begin{array}{l}\text { before - } \\
\text { after }\end{array}$ & 15.70000 & 3.74314 & 1.18369 & 13.02232 & 18.37768 & 13.264 & 9 & .000 \\
\hline
\end{tabular}

From the table above, it can be seen that the significance value indicates 0,000 where the value of sig. $<0.005$ this indicates that $\mathrm{H} 0$ was rejected and $\mathrm{Ha}$ was accepted. It means that the management of organizational behavior before is not the same as after the group counseling discussions.

Based on the questionnaire processing related to radicalism and organizational behavior management, the results of the study showed that among the management of the organization was still indicated to be radical, only that it was still at a harmless level (Swank \& Houseknecht, 2019). This can be seen from the average score obtained from the processing of the questionnaire which got a score of 57.9 which is included in the quite radical category (Hamel, 1959). Why there is still indication of this, in line with the opinion of Komarudin Hidayat which is because of the enthusiasm that sees social, political and economic realities that have not improved, such as poverty, corruption, indifference to political elites, and the absence of tangible achievements by the government (Hidayat, 2011).

This is what makes students feel they have a desire to implement Islamic values which are expected to make the Indonesian people go forward like in the past. With regard to the management of organizational behavior, the results of the questionnaire processing show that the management of organizational behavior in LDK Cahaya Islam IAIN Curup is classified in the bad category. This can be seen from the average score obtained is 38.8 which is at the interval of management assessment of organizational behavior that is not good. Why does this happen because of lack of understanding of students as organizers of organizations about organizational management. Lack of student understanding with other is still held. LDK administrators still have a lot to learn and put together communication so that the organization can run as expected (Gerber \& Singer, 1969). Counselors must understand what is done so that it does not fail to provide input to clients, this is very influential on the success of group counseling, especially in the management of organizational behavior (Li \& Kivlighan, 2014).

Group counseling discussion activities become one of the ways in efforts to manage organizational behavior because in this activity, students as group members can indirectly understand the characteristics of group members, such as their hobbies and perspectives. Knowledge about this will affect the sense of emotional bond between students as the management of the organization. This emotional bond is what makes a sense of togetherness and cohesiveness that will unite the activities of members in achieving organizational goals. From this group counseling discussion activity the students had issued their comments to the other members. As many administrators do not know about LDK activities, it turns out they do not always update the information that is shared in the LDK management group.

With the disclosure of the stewards of the organizers of this organization, the obstructed communication taps that make the organization not compact, can be open and channeled through group counseling discussions. As explained by John, M Ivancevich, et al that an organization needs to understand the behavior of individuals in it (Ivancevich, 2005). This group counseling discuss activity can help students understand the behavior of other members through observing the attitudes, personality, perceptions, learning, and motivation of individuals in these activities (Konopaske et al., 2017). From the results of this group counseling discuss activity, the students wished that the LDK organization was not accused of being radical, so they wished to collaborate with other student activity units at IAIN Curup.

In group counseling discuss activities all group members are given the opportunity to develop and realize their own independence. This opportunity makes group members know and understand the nature and 
attitudes of each member. However, this attitude of self-realization certainly cannot violate the rules in the group where all members are obliged to maintain a conducive group life. So that the independence of each member needs to be accompanied by an attitude of tolerance that is harmonious, harmonious and balanced. Group dynamics arising from group counseling discuss activities are in the context of personal development that gives birth to the attitudes, skills, and social courage that tolerate (Hartinah, 2009).

Group counseling discuss activities, teaching group members to respect all differences. Differences in perspective, differences in preferences, differences in objectives that are addressed with tolerance, will give birth to a sense of unity. This is very much in line with the objectives of the Ministry of Religion of the Republic of Indonesia in the effort of religious moderation where seeking equality is not even sharpening differences (Ministry of Religion of the Republic of Indonesia, 2019). The character of religious moderation launched by the Ministry of Religion is to emphasize openness, acceptance and cooperation from each different individual or group.

\section{Conclusion}

The description of radicalism behavior among the administrators of LDK IAIN Curup, with an average score of 57.9 shows, that the behavior of radicalism in the category is quite radical. The description of the management of organizational behavior among the administrators of IAIN Curup Campus Islamic Institution in Curup is in the bad category with an average rating score of 38.8. From the implementation of group counseling discussions, it can be concluded that the material which is the topic of discussion in groups is about radicalism and organizational behavior management. This group counseling discussion activity discusses issues of radicalism and organizational management issues, discusses the factors that cause problems and efforts that can be made so that an organization can be avoided and far from the acts of radicalism. Group dynamics that occur in group counseling discussion activities are also good seen from the enthusiasm and cohesiveness of students in discussions. Significance value shows 0,000 where the value of sig. $<0.005$ this means that $\mathrm{HO}$ is rejected and $\mathrm{Ha}$ is accepted. It means that radicalism behavior and organizational behavior management before being given group. This research has a positive effect on counselors at college, especially at IAIN Curup, which is able to conduct effective group counseling discussions so that this service is a favorite service for students on campus. Therefore the leadership in colleges should provide support both in terms of morals, material and spiritual so that counselors can provide group counseling discussion services effectively and continuously.

\section{Acknowledgment}

The authors would like to thank IAIN Curup and the Ministry of Religions Affairs, which has funded this study based on the contracts number SP.DIPA-025.04.2.308145/2019 and 0537/In.34/R/PP.00.9/06/2019.

\section{References}

Acadia, S. (2019). The Organizational Trap-Gap Framework: A conceptual view of library dysfunction. IFLA Journal. https://doi.org/10.1177/0340035219870199

Auwärter, T. (2014). "Kämpfe um die Religion" -Der Bremer Radikalismus und der Diskurs um die Zivilreligion und Leitkultur im wilhelminischen Deutschland. Zeitschrift Fur Religionswissenschaft, 22(2), 176-225. https://doi.org/10.1515/zfr-2014-0009

Berg, R. C., Landreth, G. L., \& Fall, K. A. (2013). Group counseling: concepts and procedures (4th ed.). Routledge.

Bland, M., Melang, P., \& Miller, D. (1986). The effect of small-group counseling on underachievers. Elementary School Guidance \& Counseling, 20(4).

Chen, M., \& Rybak, C. (2020). Group Leadership Skills: Interpersonal Process in Group Counseling and Therapy. In Group Leadership Skills: Interpersonal Process in Group Counseling and Therapy. https://doi.org/10.4135/9781071800980

Cornish, M. A., Wade, N. G., \& Post, B. C. (2012a). Comfort with Spiritual Discussions Measure. In PsycTESTS. https://doi.org/10.1037/t13108-000

Cornish, M. A., Wade, N. G., \& Post, B. C. P. (2012b). Attending to religion and spirituality in group counseling: Counselors' perceptions and practices. Group Dynamics, 16(2). 
https://doi.org/10.1037/a0026663

Davids, N. (2017). Islam, moderation, radicalism, and justly balanced communities. Journal of Muslim Minority Affairs, 37(3), 309-320. https://doi.org/10.1080/13602004.2017.1384672

Diab, M. I., Ibrahim, A., Abdallah, O., El-Awaisi, A., Zolezzi, M., Ageeb, R. A., Elkhalifa, W. H. I., \& Awaisu, A. (2020). Perspectives of future pharmacists on the potential for development and implementation of pharmacist prescribing in Qatar. International Journal of Clinical Pharmacy. https://doi.org/10.1007/s11096-019-00946-9

Erikson, E. H. (2018). Identity: Youth and crisis (15th ed.). WW Norton \& Company.

Erlygina, E., \& Abramova, Y. (2019). Organizational Culture as a Factor of Organizational Innovativeness. Bulletin of Science and Practice, 5(11). https://doi.org/10.33619/2414-2948/48/31

Fadli, R. P., Alizamar, A., Afdal, A., \& Ifdil, I. (2019). Psychological Well-Being of Youth Inventory on Domestic Violence Victims: Rasch Model Analysis. Journal of Couns-Edu, 4(2), 69-77.

Fanani, A. F. (2013). Fenomena Radikalisme di Kalangan Kaum Muda. Maarif: Arus Pemikirian Islam Dan Sosial, 8(1), 4-13.

Fathurrochman, I. (2017). Implementasi Manajemen Kurikulum Dalam Upaya Meningkatkan Mutu Santri Pondok Pesantren Hidayatullah Curup. Tadbir : Jurnal Studi Manajemen Pendidikan, 1(1), 85-104. https://doi.org/10.29240/jsmp.v1i1.216

Gerber, S. A., \& Singer, D. (1969). Dynamic group counseling with mothers of students in special classes. Corrective Psychiatry \& Journal of Social Therapy, 15(2).

Hamel, L. B. (1959). Counseling and Learning Through Small-Group Discussions by Helen I. Driver. The Catholic Counselor and Readings, 3(3). https://doi.org/10.1002/j.2161-007x.1959.tb00028.x

Harrington, J., \& Manji, A. (2017). The Limits of Socio-Legal Radicalism: Social and Legal Studies and Third World Scholarship. Social and Legal Studies, 26(6), 700-715. https://doi.org/10.1177/0964663917729874

Hartinah, S. (2009). Konsep dasar bimbingan kelompok (1st ed.). Refika Aditam.

Hidayat, K. (2011). Pluralitas Agama: Kerukunan Dan Keragaman (1st ed.). Kompas.

Ifdil, I., Zola, N., \& Fadli, R. P. (2019). Ifdil perceptual light technique (IPLT) an alternative brief approach for the reduction of trauma, phobia and psychological problems. Jurnal Konseling Dan Pendidikan, $7(2), 50-57$.

Ivancevich, J. M. (2005). Administración de recursos humanos (1st ed.). McGraw-Hill Interamericana.

Jones, S., Sarapung, E., Najib Azca, M., Menchik, J., Jaffrey, S., Firawati, T., Abidin, Z., Disunting, B., Mubarok, H., \& Rafsadi, I. (2015). Sisi Gelap Demokrasi (H. Mubarok \& I. Rafsadi (eds.); 1st ed.). Pusat Studi Agama dan Demokrasi Yayasan Paramadina.

Khozin, W. (2013). Sikap Keagamaan Dan Potensi Radikalisme Agama Mahasiswa Perguruan Tinggi Agama. EDUKASI: Jurnal Penelitian Pendidikan Agama Dan Keagamaan, 11(3), 289-304. https://doi.org/10.32729/edukasi.v11i3.415

Konopaske, R., Robie, C., Ivancevich, J., \& October, W. (2017). A preliminary model of spouse influence on managerial global assignment willingness.

Li, X., \& Kivlighan, D. M. J. R. (2014). Misconceptions of Group Counseling Trainees in Knowledge Structures About Group Situations. In Misconceptions of Group Counseling Trainees in Knowledge Structures About Group Situations. https://doi.org/10.1037/e552322014-001

Moagi, M., Mulaudzi, M., \& Van Der Wath, A. (2020). Support programs for students at higher education institutions in South Africa: an appreciative inquiry study on managing alcohol abuse. Journal of Substance Use, 25(1). https://doi.org/10.1080/14659891.2019.1664664

Muazza, M., Mukminin, A., Habibi, A., Hidayat, M., \& Abidin, A. (2018). Education in Indonesian islamic boarding schools: Voices on curriculum and radicalism, teacher, and facilities. Islamic Quarterly, 62(4), 507-536.

Novianty, I. (2019). The Quality Of Management Accounting Information Systems From Users' Ethics, Environmental Uncertainty, And Top Management (An Empirical Case Of Local Government In Indonesia). 20(1), 1-10.

Novitra, R. (2018, June). Penangkapan di Universitas Riau dan Radikalisme di Kampus. Tempo.Co, 1.

Prayitno, \& Amti, E. (1999). Dasar-dasar bimbingan dan konseling. PT Rineka Cipta.

Qodir, Z. (2014). Radikalisme Agama Di Indonesia (H. J (ed.); 1st ed.). Pustaka Pelajar.

Ristianti, D. H. (2017). Analisis Hubungan Interpersonal Mahasiswa terhadap Dosen dalam Proses Bimbingan Skripsi. Islamic Counseling : Jurnal Bimbingan Konseling Islam, 1(1), 25. https://doi.org/10.29240/jbk.v1i1.229

Ristianti, D. H., Danim, S., Winarto, H., \& Dharmayana, W. (2019). The Development Of Group Counselling Assessment Instruments. International Journal Of Scientific \& Technology Research, 
8(10). www.ijstr.org

Sepehrian Azar, F., \& Saadatmand, S. (2015). The Effect of Life Skills Training and Group counseling via Emotional-Behavioral-Rational Therapy on Academic Self-Concept, Achievement Motivation and Mental Health of Underachievers. JSR, 16(1), 66-77.

Supriadi, Y. N., Ahman, E., Wibowo, L. A., \& Furqon, C. (2019). Organizational citizenship behavior model for turnover intention management. International Journal of Recent Technology and Engineering, 8(2 Special Issue).

Susilawati, S., Wibowo, M. E., \& Sunawan, S. (2020). Moral Disengagement and Classroom Incivility against the Social Responsibility Character of Junior High School Students. Islamic Guidance and Counseling Journal, 3(1), 26-31. https://doi.org/10.25217/igcj.v3i1.661

Swank, J. M., \& Houseknecht, A. (2019). Teaching Competencies in Counselor Education: A Delphi Study. Counselor Education and Supervision, 58(3), 162-176. https://doi.org/10.1002/ceas.12148

Tajri, I., \& Chandra, E. K. (2018). The impact of Rational-Emotive Counseling Group Model to Modify the Delinquency of Javanese Students. Islamic Guidance and Counseling Journal, 1(2), 81. https://doi.org/10.25217/igcj.v1i2.225

Taufik, T., Fadly, R. P., \& Putri, Y. E. (2019). Development and validation of modules improving selfawareness excellent services of academic staff. Journal of Couns-Edu, 4(3), 94-101.

Thapa, K., Dhital, R., Rajbhandari, S., Mishra, S., Subedi, S., Dotel, B. R., Vaidya, S., Pande, S., Tunnacliffe, E. A., Makins, A., \& Arulkumaran, S. (2020). Improving post-partum family planning services provided by female community health volunteers in Nepal: A mixed methods study. BMC Health Services Research, 20(1). https://doi.org/10.1186/s12913-020-4969-1

Trijayanti, Y. W., Nurihsan, J., \& Hafina, A. (2019). Gestalt Counseling with Empty Chair Technique to Reduce Guilt among Adolescents at Risk. Islamic Guidance and Counseling Journal, 2(1), 1. https://doi.org/10.25217/igcj.v2i1.302

Van Der Pas, M., \& Walczuch, R. (2019). Behavior of organizational agents on managing information technology. Advances in Intelligent Systems and Computing, 857. https://doi.org/10.1007/978-3030-01177-2_57

Walton, S. (2020). Why the critical race theory concept of 'White supremacy' should not be dismissed by neo-Marxists: Lessons from contemporary Black radicalism. Power and Education, 12(1), 78-94. https://doi.org/10.1177/1757743819871316

Wibowo, M. E. (2005). Konseling kelompok perkembangan. UNNES Press.

Winkel, W. S., \& Hastuti, M. S. (2005). Bimbingan dan konseling di institusi pendidikan (5Th ed.). Media Abadi.

Yanto, M., \& Fathurrochman, I. (2019). Manajemen kebijakan kepala madrasah dalam meningkatkan mutu pendidikan. Jurnal Konseling Dan Pendidikan, 7(3), 123-130. https://doi.org/10.29210/138700

Yusuf, A. M. (2016). Metode penelitian kuantitatif, kualitatif \& penelitian gabungan (1st ed.). Prenada Media. 